\title{
The application of tetrazolium bioautography to the identification of folic acid derivatives
}

\author{
R. J. LEEMING' ${ }^{1}$, HEATHER PORTMAN-GRAHAM, C. H. J. SWAN, AND \\ J. A. BLAIR \\ From the General Hospital, Birmingham, and the University of Aston in Birmingham
}

SYNOPSIS Tetrazolium bioautography has been applied to the identification of folates in solutions of known concentration, and satisfactory resolution has been obtained between pteroyl-L-monoglutamic acid, calcium leucovorin, and N-5-methyltetrahydrofolic acid. The technique is suitable for the identification of folates in biological solutions, and is more specific than differential microbiological assay.

Bioautographic techniques combine paper chromatography with the response of microorganisms to the presence of growth factors. The procedure was first used to separate and identify members of the vitamin $\mathbf{B}_{6}$ group by Winsten and Eigen (1948), and later applied semi-quantitatively to the growth factors for $L$. casei, $S$. faecalis, and Pediococcus cerevisiae by Usdin, Shockman, and Toennies (1954). Tetrazolium compounds are reduced to deeply coloured formazan derivatives by growing bacteria as shown by Kuhn and Jerchel (1941), and this principle is used to identify the zones of enhanced growth at the site of concentration of growth factors on paper chromatograms. These techniques have been applied to the separation and identification of folic acid derivatives in various solvent systems.

\section{Materials and Methods}

TRIPHENYL-TETRAZOLIUM CHLORIDE MEDIUM (TTC)

Single strength folic acid casei medium (Difco) was made up to $500 \mathrm{ml}$ per plate containing $50 \mathrm{ml}$ $0.1 \mathrm{M}$ phosphate buffer $p \mathrm{H} 6 \cdot 1,0.5 \mathrm{~g}$ ascorbic acid, $11 \mathrm{~g}$ agar (Oxoid Ionagar no. 2), $10 \mathrm{ml} 2 \%$ aqueous tetrazolium salt (2:3:5-triphenyl-tetra-

Received for publication 8 October 1969.

'Requests for reprints should be addressed to $R$. J. Leeming,

General Hospital, Birmingham 4. zolium chloride), and $10 \mathrm{ml}$ washed suspension of $L$. casei (N.C.1.B 8010) prepared to an optical density of 0.128 at a wavelength of $650 \mu$. The last two ingredients were added after the basic medium had been prepared, sterilized, and cooled to $45^{\circ} \mathrm{C}$.

PLAIN AGAR

For each plate, $3.5 \mathrm{~g}$ agar (Oxoid Ionagar no. 2) was dissolved in $300 \mathrm{ml}$ distilled water.

STOCK SOLUTION OF FOLIC ACID DERIVATIVES

The following solutions were prepared at a concentration of $1 \mathrm{mg}$ per $\mathrm{ml}$ in $1 \%$ aqueous ascorbic acid and stored at $-20^{\circ} \mathrm{C}$ in $0.5 \mathrm{ml}$ aliquots: pteroyl-L-monoglutamic acid (Sigma), calcium leucovorin (Lederle), and N-5-methyltetrahydrofolic acid (Department of Chemistry, University of Aston).

\section{SOLVENT SYSTEMS TESTED}

The following solvent systems were used: (1) $3 \%$ aqueous ammonium chloride; (2) $5 \%$ aqueous acetic acid; (3) $0.5 \%$ sodium bicarbonate; (4) $0.1 \mathrm{M}$ phosphate buffer $p \mathrm{H} 6.0$; (5) $0.1 \mathrm{M}$ phosphate buffer $p \mathrm{H} 6.5 ;(6) 0.1 \mathrm{M}$ phosphate buffer $p \mathrm{H} \mathrm{7.0;} \mathrm{(7)} \mathrm{saturated} \mathrm{aqueous} \mathrm{disodium} \mathrm{hydrogen}$ phosphate; (8) $0.2 \mathrm{M}$ acetate buffer $p \mathrm{H} \mathrm{5.0;} \mathrm{(9)}$ 
$2 \%$ aqueous sodium chloride; and (10) $1 \%$ aqueous ascorbic acid. Except for solvent system no: 10 , all systems contained $1 \%$ ascorbic acid as an anti-oxidant.

\section{Preparation of the Bioautographs}

Ascending paper chromatograms were prepared on Whatman no. 1 chromatography paper and were developed for 60 minutes at room temperature in the dark. Each bioautograph plate was prepared by pouring $250 \mathrm{ml}$ of the TTC medium described above into a culture dish measuring $30 \mathrm{~cm} \times 30 \mathrm{~cm} \times 2.5 \mathrm{~cm}$ and allowing to set. The developed and partially dried chromatogram was then laid on top of this layer and a further $250 \mathrm{ml}$ of TTC medium was poured on. The whole preparation was then covered with $300 \mathrm{ml}$ plain agar. Each plate was then incubated at $37^{\circ} \mathrm{C}$ overnight.

In assessing the suitability of the various solvent systems, the stock solutions of pteroylL-monoglutamic acid, calcium leucovorin, and $\mathrm{N}$-5-methyltetrahydrofolic acid were diluted in $1 \%$ aqueous ascorbic acid to give the following working solutions: pteroyl-L-monoglutamic acid $0.1 \mu \mathrm{g}$ per $\mathrm{ml}$; calcium leucovorin $1.0 \mu \mathrm{g}$ per $\mathrm{ml}$; and $\mathrm{N}-5$-methyltetrahydrofolic acid $1.0 \mu \mathrm{g}$ per $\mathrm{ml}$.

A mixture containing all three of the above solutions in similar final concentration was also prepared.

In testing the solvent systems, $10 \mu \mathrm{l}$ of each folate was applied to the chromatograms and developed simultaneously in the manner described above.

To test the sensitivity of the technique, serial 10 -fold dilutions of the solutions of folates were prepared and at each stage of dilution $10 \mu \mathrm{l}$ volumes were added to strips of chromatography paper. These strips were not developed chromatographically, but were incorporated into the bioautograph plates in an identical manner to the

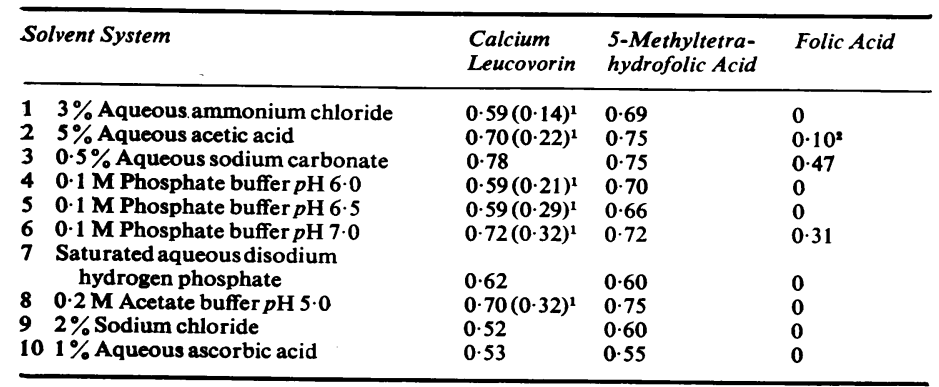

Table $R_{\mathbf{f}}$ values for folic acid derivatives in 10 solvent systems

${ }^{1}$ Minor spot.

${ }^{2}$ Elongated spot. developed chromatograms. Chromatograms were developed with $3 \%$ aqueous ammonium chloride and $0.1 \mathrm{M}$ phosphate buffer $p \mathrm{H} 7.0$ as solvents in which $10 \mu \mathrm{l}$ of solutions of pteroyl-L-monoळ glutamic acid, calcium leucovorin, and N-5 methyltetrahydrofolic acid had been applied atp the origin. This series was repeated using ine creasing dilutions of each solution, such that the concentrations applied were $5 \mathrm{ng}$ per $10 \mu \mathrm{l}, 1 \mathrm{ng}$. per $10 \mu \mathrm{l}, 500 \mathrm{pg}$ per $10 \mu \mathrm{l}, 100 \mathrm{pg}$ per $10 \mu \mathrm{l}$, an\& 50 pg per $10 \mu \mathrm{l}$.

\section{Results}

TESTS OF SUITABILITY OF SOLVENT SYSTEMS After incubation at $37^{\circ} \mathrm{C}$ overnight the position of each folate was revealed as a dark red spots The $R_{f}$ values obtained for each folic acid derivative in the 10 solvent systems used are shown in the Table. The best separation and definition of spots was obtained using $3 \%$ aqueou $\leftleftarrows$ ammonium chloride and $0 \cdot 1 \mathrm{M}$ phosphate buffer pH 7.0.

TESTS OF SENSITIVITY OF THE TECHNIQUE Using strips of chromatography paper impreg nated with $10 \mu 1$ of pteroyl-L-monoglutamic acid calcium leucovorin, and N-5-methyltetrahydro folic acid in serial 10-fold dilutions using $1 \%$ aqueous ascorbic acid as diluent, it was found that a concentration of $100 \mathrm{pg}$ per $10 \mu \mathrm{l}$ could be detected unequivocally as a zone of red colori zation after incubation.

In a series of progressive dilutions of knowig concentration as above, using $3 \%$ aqueous ammonium chloride and $0 \cdot 1 \mathrm{M}$ phosphate buffe

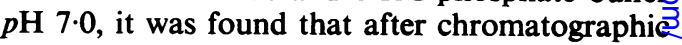
development both calcium leucovorin and N-5옹 methyltetrahydrofolic acid cound be detected at a concentration of $500 \mathrm{pg}$ per $10 \mu \mathrm{l}$ and pteroy? monoglutamic acid at a concentration of $100 \mathrm{pg}$ per $10 \mu 1$.

\section{Discussion}

The techniques whereby semi-quantitative mea? surements may be applied to bacterial growtho zones using differential microbiological assay have previously been described by Usdin et aD (1954). Tetrazolium bioautography has now beerp applied to the identification of folic acid derivatives using solutions of known content ans concentration. A satisfactory bioautographico technique has been established with two solvent systems (nos. 1 and 4) which provides adequate resolution between the three folates studied? Identification of calcium leucovorin and N-5- 
methyltetrahydrofolic acid is thus possible in the range $10-50 \mathrm{ng}$ per $\mathrm{ml}$, and identification of pteroyl-L-monoglutamic acid in the range of 5 to $10 \mathrm{ng}$ per $\mathrm{ml}$. Although these levels are still in excess of those in serum, suitable levels can be attained by concentration and the various folates present readily identified. Folates are present in urine in sufficient quantities to allow identification without concentration.

\section{References}

Kuhn, R., and Jerchel, D. (1941). Reduction of tetrazolium salts by bacteria, fermenting yeast and germinating seeds. Ber. dtsch. chem. Ges., 74B, 949-952.

Usdin, E., Shockman, G. D., and Toennies, G. (1954). Tetra- $\stackrel{\mathscr{O}}{\vec{D}}$ zolium bioautography. Appl. Microbiol., 2, 29-33.

Winsten, W. A., and Eigen, E. (1948). Paper partition chromatographic analysis and microbial growth factors: the vitamin Ba group. Proc. Soc. exp. Biol. (N.Y.), 67, 513-517. 